\title{
To study natural herbal dyes on cotton fabric to improving the colour fastness and absorbency performance
}

\begin{abstract}
Nowadays, all consumers are more preference for the natural herbal textile dye garment products. These herbal dye cloths are more eco friendly products. It is give non-toxic, chemical free product and this does not harmful environment nature. Herbal textile is dyed entirely with herbal extraction, without using any sort of chemical. The herbs used different from vegetable dyes as they are not only natural but also have medicinal value. These herbs are applied directly to the fabric with the help of natural ingredients, So that the medicinal value of the herbs can be kept intact, because synthetic dyes large amount of waste and unfixed colorants poses serious health hazard and are disturbing the eco balance of nature. Environmental issues in the production and application of synthetic dyes once again revived consumer interest in natural dyes. In this research work we have applied natural herbal dyes on cotton fabrics surface. This work has used natural herbal dyes like turmeric, aloe vera, neem, beetroot, pomegranate and onion. Edible gum and cow urine has used to improve in colour fastness and dye absorbency performance. This research main aims to give a new approach natural herbal dyes products will more used in textile sector. It will more help to reduce diseases problem skin allergies and skin infection.
\end{abstract}

Keywords: cotton fabric, edible gum, cow urine, wash fastness, rubbing fastness, colour fastness to light
Volume 7 Issue 2 - 202I

\author{
Rohit Kumar,' Ramratan, ${ }^{2}$ Anupam Kumar, ${ }^{3}$ \\ Devanand Uttam ${ }^{3}$ \\ 'Research Schlaor, Department of Textile Engineering, Giani Zail \\ Singh Campus, College of Engineering and Technology, Maharaja \\ Ranjit Singh Punjab Technical University, India \\ ${ }^{2}$ Assistant Professor, Department of Textile Engineering, Giani \\ Zail Singh Campus, College of Engineering and Technology, \\ Maharaja Ranjit Singh Punjab Technical University, India \\ ${ }^{3}$ Professor, Department of Textile Engineering, Giani Zail Singh \\ Campus, College of Engineering and Technology, Maharaja Ranjit \\ Singh Punjab Technical University, India
}

Correspondence: Ramratan, Assistant Professor, Department of Textile Engineering, Giani Zail Singh Campus, College of Engineering and Technology, Maharaja Ranjit Singh Punjab Technical University, Bathinda, Punjab, India, Tel +91-9781547442, Email ramratan333@gmail.com

Received: February 20, 2021 | Published: March 30, 2021

\section{Introduction}

Natural dyes are found from natural sources such as from plants, animals and mineral. But the natural colour may not have the desired shade or fastness, it was also scarce and costly but natural dyes applied without using any sort of chemical. These are applied directly to the fabric with the help of edible gum and cow urine. No chemical is used in its dyeing process. Whereas some chemicals such copper sulfate and ferrous sulfate are used as catalysts. ${ }^{1,2}$ The fabric is $100 \%$ cotton free from any chemical, making the free from toxins and irritants with people becoming increasing health conscious the world over. Herbal treated such as neem, turmeric, aloe vera, pomegranate, onion cloth has the ability to protect from various skin diseases, provides relief from viral infected disease and mental depression since herb finished clothes or garments come in prolonged contact with the human body. The medical properties of herb no damage to the human body and protective the various skin infections but the case of synthetic dyes is available and cheap for commercial use. ${ }^{3-6}$ It is extremely harmful environment and health as it leaves a tremendous amount of waste and allergic in contact with human body. And now a day the environmental issue is rising all over the world. This is the main reason of transferring to natural dyes from synthetic dyes. The main purpose of using natural dye is to make the process eco-friendly and hygienic..$^{7-9}$ Most of the commercial dyers and textile export houses have started re-looking to the maximum possibilities of using natural dyes for dyeing and printing of different textiles for targeting niche market. Natural dyes produce very uncommon, soothing and soft shades as compared to synthetic dyes. ${ }^{10-14}$ On the other hand, synthetic dyes, which are widely available at an economical price and produce a wide variety of colours, sometimes causes skin allergy and other harmfulness to human body, produces toxicity/chemical hazards during its synthesis, releases undesirable/hazardous/toxic chemicals etc. The wide varieties of exotic shades produced by natural dyes are parallel with the synthetic range and hence can replace them with ease. At present, little information in this aspect is available. ${ }^{15-18}$ Natural dyes are being considered as a more environmentally friendly substitute for synthetic dyes but these have few draw backs low colourfastness property is one. But no study reported on improving the colourfastness properties of natural dyes with a natural dye fixing agents. So, in this article results were shown the improvement of colour fastness of natural dyes with natural dye fixing agents.

\section{Material and method}

(Figure 1) (Table 1)

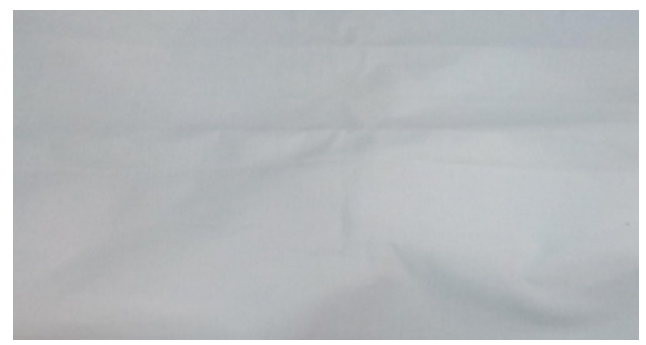

Figure I 100\% Cotton woven fabric.

Table I Fabric specifications

\begin{tabular}{lll}
\hline S. No & Type & 100\% cotton woven fabric \\
\hline I & Warp count & 20 \\
2 & Weft count & 20 \\
3 & EPI & 56 \\
4 & PPI & 42 \\
5 & GSM & 124 \\
6 & Weave design & Plain \\
\hline
\end{tabular}




\section{Turmeric}

Turmeric belongs to some family as ginger. Turmeric is the most popular dye in textile dyeing. Turmeric is a rich source of phenolic compound is known as curcuminoids. It has antioxidant and skin lightening properties and might to be used to treat skin inflammation making. These compounds are useful in cosmetic formulation. Turmeric was and is still used for textile painting and printing in India (Figure 2).

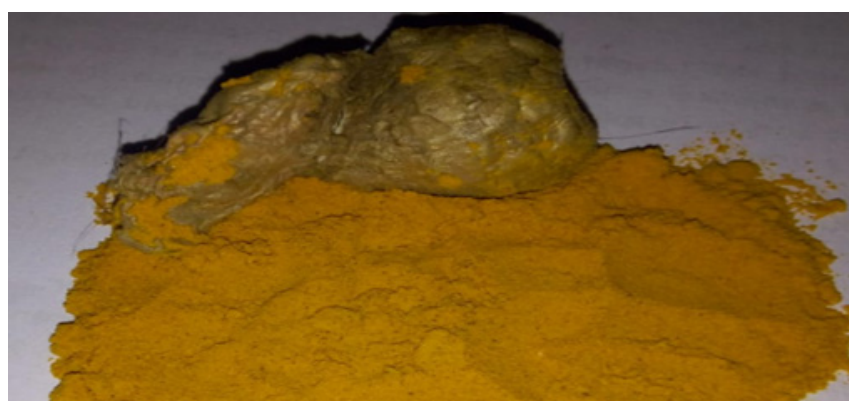

Figure 2 Turmeric.

\section{Neem}

Neem is a natural herb that comes from the neem leaves. Another name for which include azadirachtaindica. Neem leaves can produce light yellow green color in cotton fabric. The main reason of choice neem leaves has antibacterial properties. The nano emulsion of neem at lower concentration can be used as an effective antibacterial agent for treatment of pathogenic bacterial infection without any toxicity to human system (Figure 3).

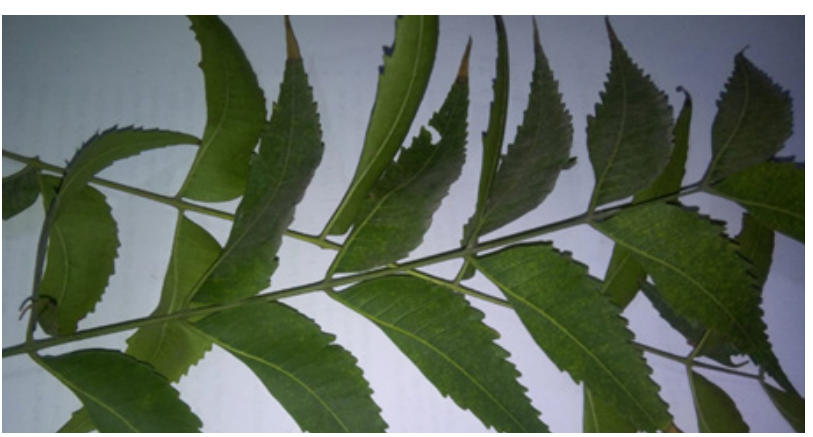

Figure 3 Neem paste.

\section{Aloe vera}

Aloe Vera is a succulent plant species of the genus aloe. Aloe vera is a medicinal plant that's been used to treat various health conditions. Aloe Vera gel uses a skin treatment. The aloe Vera plant which is about 1-2 feet tall hold leaves that contains a slushy translucent gel. The waste parts of the aloe Vera leaf could be used as a natural dye for dyeing textile fabric (Figure 4).
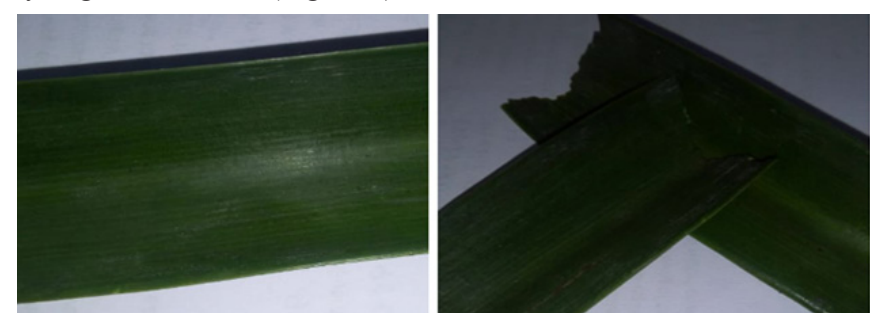

Figure 4 Aloe vera.

\section{Onion}

Using red yellow onion skins is a really fun and economical way to dye fabric. Red and yellow onion skin can produce different color. In my experience on cotton fabric, the red onion skin produce yellow with greener tones and the yellow onion skin produce more orange tones. The outer skin of this common vegetable is one of the most useful and readily available dyestuffs (Figure 5).

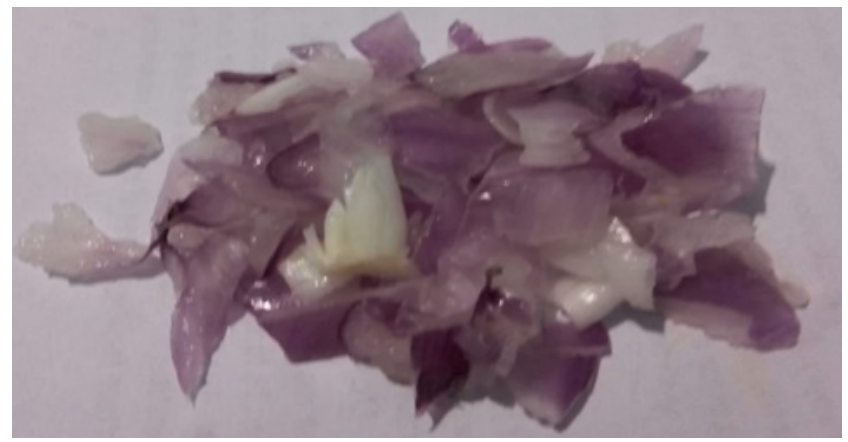

Figure 5 Onion.

\section{Beetroot}

Beetroot commonly known as beets are a popular root vegetable used in many cuisines around the world. Beetroot is the main coloring compound present in red beetroot juice color (Figure 6).

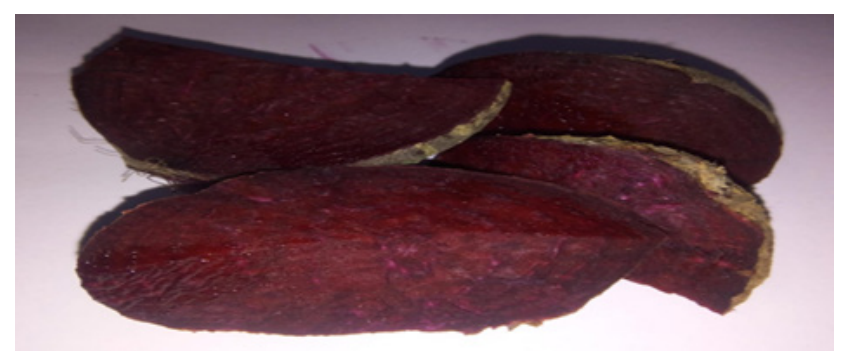

Figure 6 Beetroot juice.

\section{Pomegranate}

The pomegranate is one of the oldest fruit in cultivation and its rind has been used as a dye by carpet makers for millennia. This dye is high in tannin. Therefore it works particularly will with cotton and other plant fiber. The pomegranate fruit yield on ochre yellow dye and the skin is rich in tannin (Figure 7).

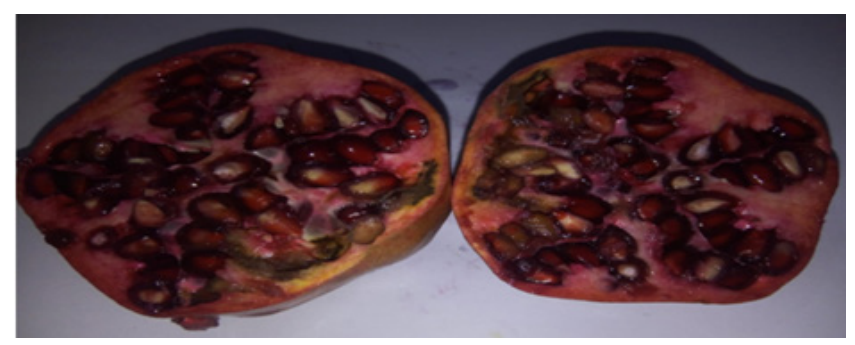

Figure 7 Pomegrante.

\section{Edible gum}

Edible gum is natural product obtained from trees. Edible gum is water soluble which makes it easy to mix with a range of ingredients. Edible gum used as a binding and a thickening agent. Edible gums are using improvetha color fastness in cotton fabric. 


\section{Cow urine}

Cow urine is a liquid by product of metabolism in cows. Cow urine is also used in medicine in India. Cow urine is a present antibacterial property. The various studies have found good antimicrobial activity of cow's urine. Cow urine can cure certain allergies, skin problems like psoriasis, skin allergies. Now day cow urine is cosmetic product. Cow urine improves the absorbency of cotton fabric.

\section{Method}

Hundred percent bleached cotton woven fabrics is used in this research work. Cotton plain weave woven fabric structures are used. According to the natural dye are used according to diseases and most widely using herbal dye such as turmeric, neem, aloe vera, onion, beetroot and pomegranate. All the process was carried out in a natural way without using any chemical, at any stage of processing. Firstly, water and cow urine are boiled together at 80:20 ratio for 30 mint and then fabric is boiled in it for 3 hours at $60^{\circ} \mathrm{C}$. It will improve the colour absorbency of the fabric. After boiling the cotton fabric are divided into 5 different pieces for different colour and different natural dyes. Secondly boiled fabric is treated with edible gum. The edible gum used as a binding agent. After boiled fabric are dipped in edible gum solutions. The water and edible solution are depending the weight of fabric. Fabric is boiled solutions $60^{\circ}$ temp. The fabric is dipped in solution and on padding machine. Adequate liquor picks up is essential 80-90 depending on weight and construction of fabric and can be achieved by a combination of absorbent fabric and long contact of the fabric with the liquor. Dyeing of cotton fabric was done with the natural coloring matter extracted from turmeric, neem, aloe Vera, onion, beetroot and pomegranate with the liquid ratio 1:40 at $100^{\circ}$ for 60 mints. The fabric sample was immersed in the dyeing solution in a water bath at $30^{\circ} \mathrm{c}$. After dyeing fabric is washing rose water because natural dye is directly applied in fabric surface, they are various smells before washing rose water, then finally fabric dry (Figures 8-10).

\section{Reason to choose natural dyes}

Economic use of natural dye is limited. They are good examples to neem, aloe Vera, turmeric, onion and pomegranate. The chemical dye are create sever environmental problem like water pollution, soil pollution and toxic nature of dye causes death to the soil microorganism which in turn affect the agricultural productivity. Synthetic dye are clothing come into prolonged contact with one's skin, the largest organ and so toxic chemical are after absorbed into the skin. The absorption has been shown to cause significant health effects, such as an increase in tumours. Textile dye can also cause allergies such as contact dermatitis and respiratory disease, allergies reaction in eyes, skin irritation and irritations to mucous membrane. These diseases are most prevalent in the workers who are dyeing the cloth as they are around the chemical all day. But natural dyes are found natural resource. No chemicals are used in its dyeing process. Natural dye are not damage to the human body protective the various skin infections.

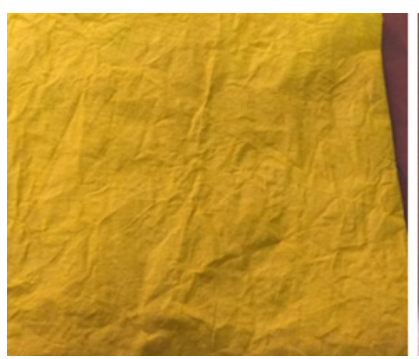

Figure 8 (a) Turmeric, (b) Beetroot.

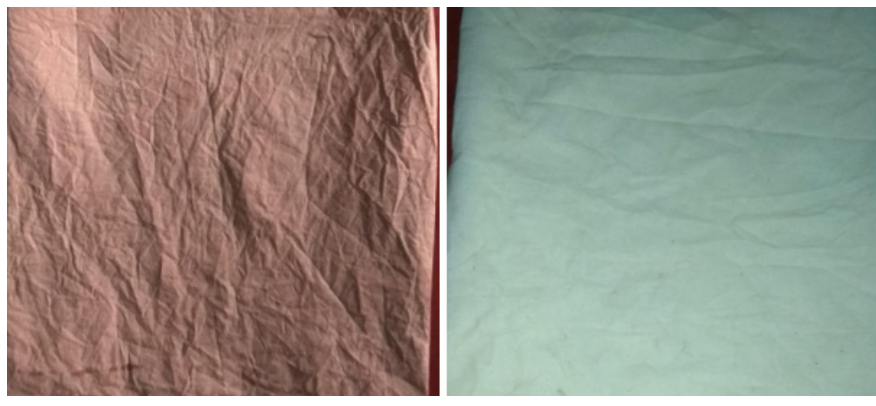

Figure 9 (a) Onion, (b) Aloe Vera.
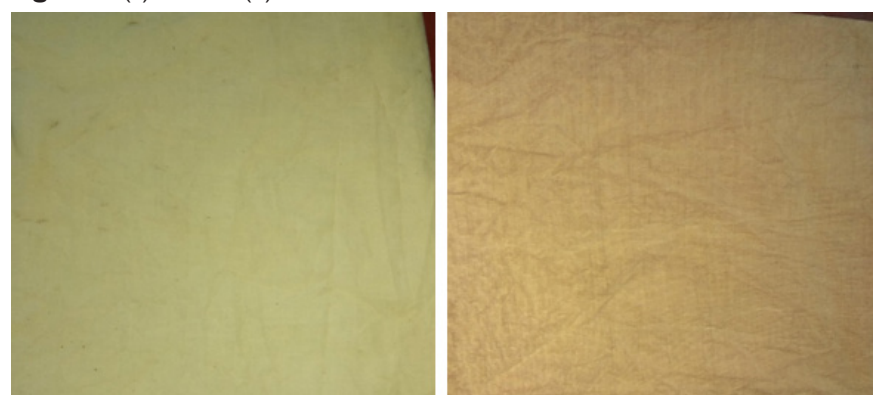

Figure 10 (a) Neem, (b) pomegranate.

\section{Dyeing process}

Dyeing of cotton fabric was done with the natural coloring matter extracted from neem, aloe Vera, turmeric, onion, beet root, pomegranate with the liquid ratio $1: 40$ at $100^{\circ} \mathrm{C}$ for 60 mint. Dyeing was performed in stainless steel vessel. The cotton fabric sample was immersed in dying solution in a water bath at $30^{\circ} \mathrm{C}$ and after dying fabric dipped rose water 10-20 mint.

\section{Colour fastness to light test}

The main purpose of colour fastness to light test determines the effect of natural sunlight and textile colour. Model TF422 found laboratory apparatus according to ISO $105 \mathrm{~B} 02$. It is most common international standards for colour fastness to light process. The sample is cut and should be exposed $1 / 2$ covers and $1 / 2$ exposed together with standard with blue wool reference (1-8). The blue scale ranges from 1 to 8.1 is very low colour fastness to light and 8 is very high colour fastness to light. The test sample exposed to light for a certain time 24 $\mathrm{hr}, 36 \mathrm{hr}, 48 \mathrm{hr}$ depend by customers demand (Figure 11).

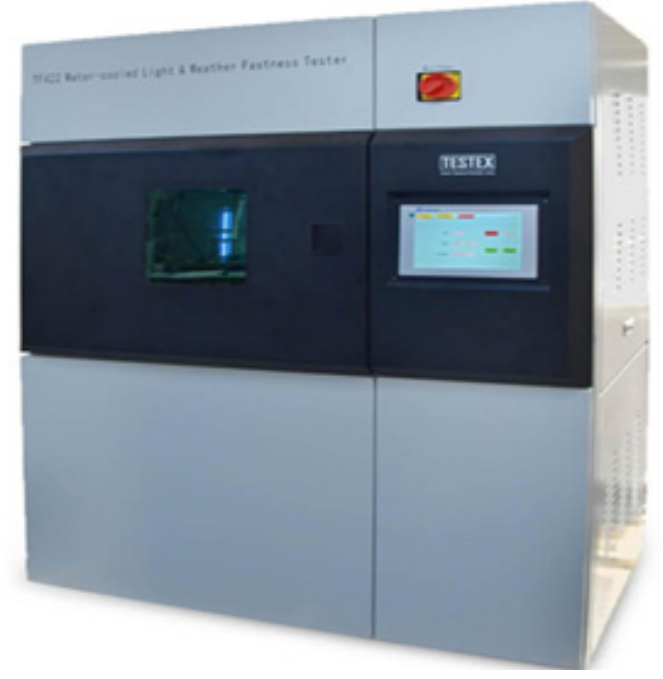

Figure I I Light fastness tester.

Citation: Kumar R, Ramratan, Kumar A, et al. To study natural herbal dyes on cotton fabric to improving the colour fastness and absorbency performance.J Textile Eng Fashion Technol. 2021;7(2):5I-56. DOI: I0.15406/jteft.2021.07.00267 


\section{Washing fastness test}

The dyed sample was washed in the launder -O- meter laboratory apparatus according to ISO 105 C06 A2S standard and model DZ307. Detergent washing testing determines the resistance of textile colour to domestic or commercial laundering procedures. The size of specimen was $40 * 100 \mathrm{~mm}$, the wash bath contained $4(\mathrm{~g} / \mathrm{l}) \mathrm{ECE}$ phosphate and $1 \mathrm{gm} /$ litre sodium perborate. The volume of the bath was $150 \mathrm{ml}$, the temperature of the bath was $40^{\circ} \mathrm{C}$ and time of washing 40 mint. Ten stainless steel balls are added into each bath to perform washing. After washing, the sample are squeezing with cold water, then drying is done at a temperature in the air not exceeding $600 \mathrm{C}$ and measuring the staining and colour change by grey scale (Figure 12).

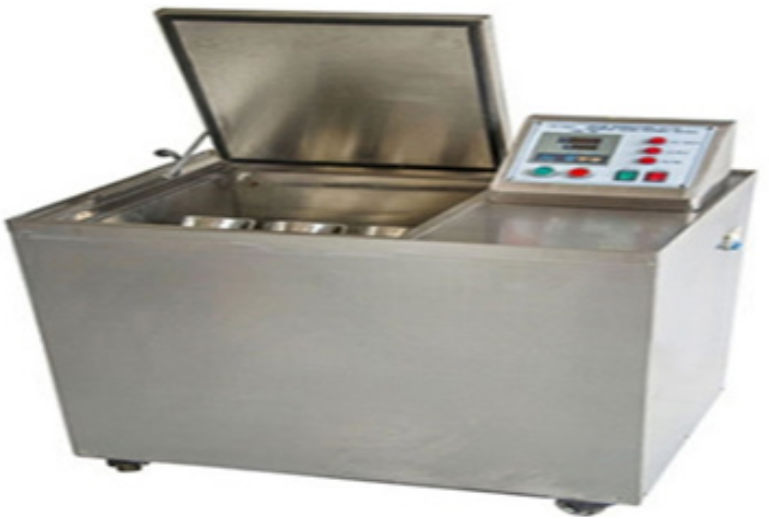

Figure 12 Colour fastness to washing tester.

\section{Rubbing fastness test}

Colour transfer testing measure the amount of colour transfer from rubbing. The crock meter is a relatively simple rub tester commonly used to determine the amount of colour transferred from textile material to other surface by rubbing. The dyed sample are rub fastness in table crock meter model 418 found laboratory apparatus according to EN ISO $150 X 12$ standard. The size of the specimen was $20 * 100 \mathrm{~mm}$ arm is weighted to provide a constant $9 \mathrm{~N}$ load on the sample at all time and a mechanical counter keeps track of completed 10 cycle. After completions of rubbing sample are dried then it is compared AATCC grey scale (ISO 105-A03) for staining of color (Figure 13).

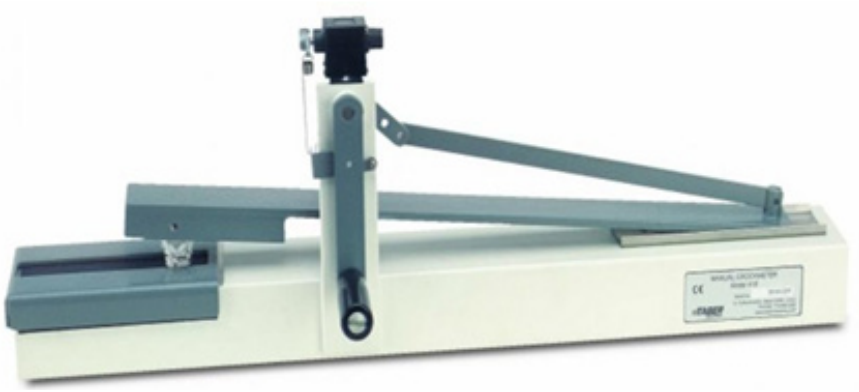

Figure I 3 Rubbing fastness tester.

\section{Colour measurements}

The spectrophotometer is a colour measurement device used to capture and evaluate colour. The most common spectrophotometer, this instrument measures light reflected at a fixed angle to the sample usually $45^{\circ}$ sample are measured using a spectrophotometer spectra flas 600 plus CT (data colour). CIE $1 * b * a$ colour value and reflectance (R) of sample were measured using reflectance spectrophotometer spectra. The CIE $1 * \mathrm{a} * \mathrm{~b}$ colour value, color differences are calculated according to equation first. $\mathrm{k} / \mathrm{s}$ value are calculated according to equation

$$
\mathrm{K} / \mathrm{S}=(1-\mathrm{R}) / 2 \mathrm{R}
$$

Where $\mathrm{R}$ is the reflectance, $\mathrm{K}$ is absorbance and $\mathrm{s}$ is the scattering.

\section{Results and discussion}

The color fastness to light, washing and rubbing of dyed cotton sample are treated with edible gum and cow urine. Edible gum used as in bending and thick agent, and cow urine is increases the fabric absorbency. The treated sample colour fastness to light test result show (Tables 2-4) (Figure 14). The blue wool scale range is used from one to eight. One is very low colour fastness to light and eight is very high colour. Almost all the sample is show by grading. All the samples are showing fairly good (4) and washing fastness grade show fairly good (3-4).

The colour change dry and wet rubbing for all samples is found to fair. But dry (2) is very good grade and wet good fastness grade. The washing fastness grades range between excellent and good (3 to 4.5) for all the treated of sample. It is found that extracted and directly applied dye from the leves, aloe Vera, turmeric, pomegranate, onion, beet root can be successfully used for dyeing of cotton fabric. Fairly, good and excellent washing, rubbing and fastness to light these data also helpful for textile industries and another laboratory work (Figure 15) (Figure 16).

Table 2 Colour fastness to light test

\begin{tabular}{lll}
\hline Sr. No. & Dye name & Grade \\
\hline 1 & Turmeric & 4 \\
2 & Neem & 3 \\
3 & Aloe Vera & 3 \\
4 & Onion & 4 \\
5 & Beet root & 4 \\
6 & Pomegranate & 4 \\
\hline
\end{tabular}

Table 3 Colour fastness to washing fastness test

\begin{tabular}{lll}
\hline Sr. No. & Dye name & Grade \\
\hline 1 & Turmeric & 4 \\
2 & Neem & 3 \\
3 & Aloe Vera & 3 \\
4 & Onion & 3 \\
5 & Beet root & 4 \\
6 & Pomegranate & 4 \\
\hline
\end{tabular}

Table 4 Rubbing fastness

\begin{tabular}{llll}
\hline Sr. No. & Dye name & $\begin{array}{l}\text { Dry rubbing } \\
\text { fastness }\end{array}$ & $\begin{array}{l}\text { Wet rubbing } \\
\text { fastness }\end{array}$ \\
\hline 1 & Turmeric & 2 & 4 \\
2 & Neem & 4 & 2 \\
3 & Aloe Vera & 4 & 4 \\
4 & Onion & 2 & 4 \\
5 & Beet root & 2 & 4 \\
6 & Pomegranate & 4 & 4 \\
\hline
\end{tabular}




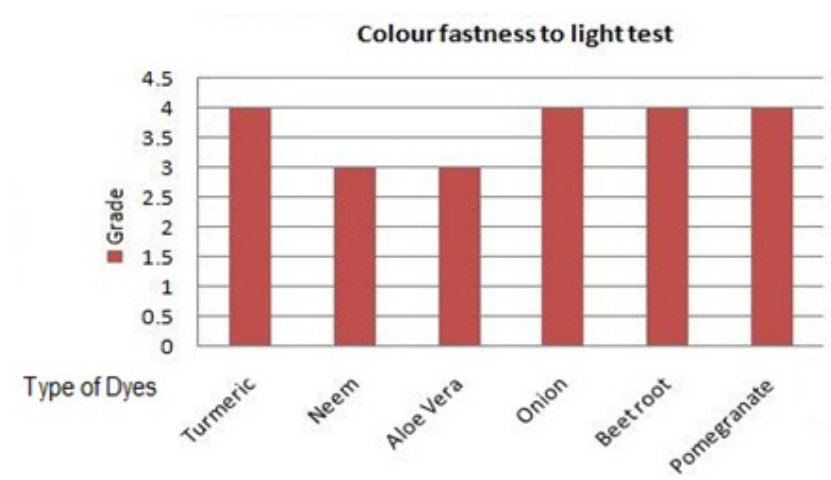

Figure 14 Natural dyes effect on colour fastness to light test.

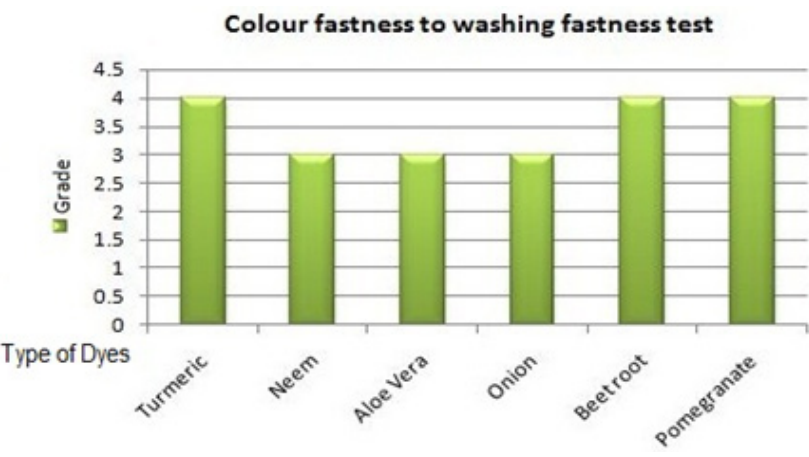

Figure 15 Natural dyes effect on colour fastness to washing fastness test.

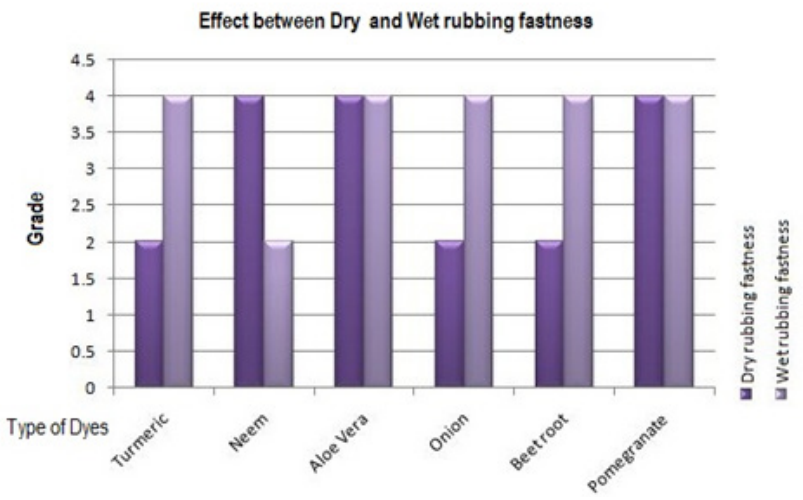

Figure 16 Natural dyes effect between on dry and wet rubbing fastness.

\section{Conclusion}

a. This research main preference to give a new approach natural herbal dyes products will more used in textile area. It will more help to reduce diseases problem skin.

b. It is to improve the colour fastness and absorbency of the natural herbal dyes on cotton fabric.

c. The natural dye is to make the process eco-friendly and hygienic than synthetic dyes.

d. We have found that herbal dyes appearances on cotton fabric surface is very good.

e. It has observed that, a dry and wet rubbing fastness property has very good herbal dyes on cotton fabric surface.

f. This work can be helpful in the development of low cost and eco-friendly health care fabric to the human.

\section{Acknowledgments}

The Authors wishes to express their heartfelt gratitude to the authorities of Giani Zail Singh Campus, College of Engineering and Technology, MRSPTU, Bathinda to provide the facilities for conducting the required test in their laboratories. Special thanks are also due to the HOD and staff member for Department textile Engineering and special thanks give to HOD and staff member for the textile engineering department.

\section{Funding}

None.

\section{Conflicts of interest}

No potential conflict of interest was reported by the authors.

\section{References}

1. Ashis KS, Priti A. Application of natural dyes on textiles. Indian Journal of Fibre Textile Research. 2009;34(1):384-399.

2. Dhara B, Padma SV. Antifungal textile dyeing with mahonianapaulensis DC leaves extract based on its antifungal activity. Fibre Polymer. 2007;8(5):487-494.

3. Thilagavathi G, Krishna Bala S. Microencapsulation of herbal extracts for microbial resistance in healthcare textile. Indian Journal Fibre Textile Research. 2007;32(1):351-354.

4. Siva R. Status of natural dyes and dye yielding plants in India. Current science. 2007;92(7):10-15.

5. Al-Maiman SA, Ahnad D. Changes in physical and chemical properties during pomegranate (Punica granatum L.) fruit maturation. Food Chemistry. 2002;76:437-441.

6. Bell C, Hawthorne S. Ellagic acid, pomegranate and prostate cancer Amini review. Journal of Pharmacy and Pharmacology. 2008;60:139-144.

7. Laha A, Gupta D. Antibacterial activity of cotton fabric treated with QuercusInfetoria extract. IJFTR. 2007;32:88-92.

8. Sateesh B, Ramachandran M. Recent trends in Indian textile industryexploring novel natural dye products and resources. International Journal on Textile Engineering and Processes. 2015;1(3):33-41.

9. Phan, TT, Hughes, MA, Cherry GW. Enhanced proliferation of fibroblasts and endothelial cells treated with an extract of the leaves of Chromolaenaodorata (Eupolin), an herbal remedy for treating wounds. Plast Reconstr Surg. 1998;101(1):756-765.

10. Banupriya J, Maheshwari V. Comparison between herbal and conventional methods in antimicrobial finishes. International Journal of Fiber and Textile Research. 2014;4(2):41-43.

11. Vijayalakshmi D, Ramachandran T. Isolates application of Multifunctional finishes on denim garments. Daffodil International University Journal of Science and Technology. 2012;7(1):59-66.

12. Thilagavathi G, Rajendra Kumar K, Rajendran R. Development of antimicrobial textile finishes from plant species. Indian Journal Fibre Textile Research. 2005;30(1):430-436.

13. Yagoub SO, Safi SEHA, Ahmed B, et al. Antimicrobial activity of some medicinal plants against some gram positive, gram negative and fungi. Phytotherapy research. 2006;14(1):329-332.

14. Ogueke CC, Ogbulie JN, Okoli IC, et al. Antibacterial activities and toxicological potentials of crude ethanolic extracts of euphorbia hirta. Journal of American Science. 2007;3(2):11-16.

15. Rangari NT, Kalyankar TM, Mahajan AA, et al. Review article: Ayurvastra Herbal couture technology in textile. International Journal of Research in Ayurveda and Pharmacy. 2012;3(5):733-736. 
16. Mathur A, Verma SK, Yousuf S, et al. Antimicrobial potential of roots of ricinuscommunis against pathogenic microorganisms. International Journal of Pharma and Bio Sciences. 2011;2(1):545-548.

17. Gupta A, Upadhyay NK, Sawhney RC, et al. Poly-herbal formulation accelerates normal and impaired diabetic wound healing. Wound Rep Regen. 2008;16(1):784-790.
18. Shivankar VS, Vyas SK. Extraction of natural dye pomegranate rind and its fastness properties. Asian Dyer Journal. 2011;2(1):57-60. 